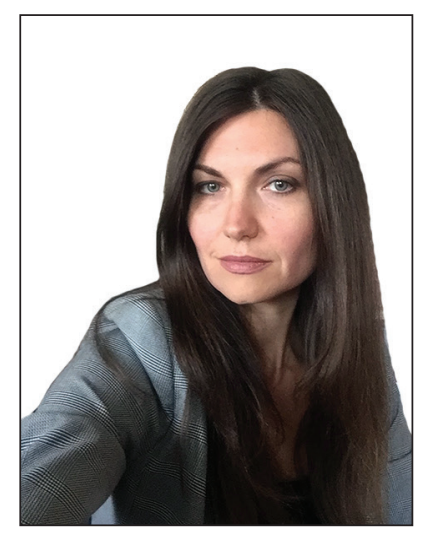

Danelciuc-Colodrovschi Nataşa, Doctor in Public Law, Assistant Researcher, Aix Marseille Univ, University of Toulon, Univ Pau \& Pays Adour, CNRS, DICE, ILF, France, Aix-en-Provence e-mail:natasa.colodrovschi-danelciuc@univ-amu.fr

doi: 10.21564/2414-990x.150.206778

UDC 342.722

\title{
THE PRINCIPLE OF EQUALITY IN THE FRENCH CONSTITUTIONAL COUNCIL'S CASE-LAW: WHAT CHANGES AFTER TEN YEARS OF EX POST REVIEW IMPLEMENTATION?
}

In France, the principle of equality has its source in a set of at least fifteen articles belonging to one of the three constitutional texts that form the "constitutional block". Because of this privileged place, which is incomparable with regard to other fundamental rights and freedoms, the principle of equality figured in almost a half of the decisions pronounced by the Constitutional Council from its creation till 2010, when the ex post review - called "procedure of QPC" - began to be implemented in France. Despite the relevant statistics, the constitutional judges' activity in this field was marked by voluntary selfrestraint. The object of this study is to analyse if in the first ten years of QPC procedure implementation their approach has changed in order to strengthen the protection of the litigants' rights and what are the technics of control they use in order to realise such changes.

Keywords: French Constitutional Council; ex ante review; ex post review; concrete control; abstract control; techniques of constitutional control; constitutional block; principle of equality; selfrestraint; protection of the fundamental rights and freedoms.

Данельчук-Колодровскі Н., докторка права, наукова співробітниця, Університет Екс Марсель, Університет Тулону, Університет По е де Пеї де Л’Адур, CNRS, DICE, ILF, Франція, м. Екс-ан-Прованс.

e-mail: natasa.colodrovschi-danelciuc@univ-amu.fr

Принцип рівності у прецедентному праві Конституційної Ради Франції: що змінюється після десяти років фактичного застосування?

У Францї принцип рівності закладено не менше ніж у п'ятнадияти статтях, що відносяться до одного з трьох конституиійних текстів, які складають «конституційний блок». Через це привілейоване місце, яке відрізняється від інших основними правами і свободами, принцип рівності фігурував майже в половині рішень, винесених Конституційною Радою з моменту ї створення аж до 2010 р., коли перегляд ех роst - так звана «процедура QPC» - почав впроваджуватись у Франції. Незважаючи на відповідні статистичні дані, діяльності конституційних суддів у чій 
сфері була притаманна добровільна стриманість. Метою даного дослідження є аналіз того, чи змінився їх підхід у перші десять років упровадження прощедури QPC для посилення захисту прав сторін $і$ які методи контролю вони використовують для реалізації таких змін.

Дослідження виявило кілька важливих моментів. Зі статистичної точки зору, принцип рівності посідає набагато важливіше місце в рамках подальшого огляду, ніж той, що був до його введення. У деяких спеціальних галузях, таких, як, наприклад, податкове законодавство, у 73 \% запитів, отриманих Конституційною Радою, законодавчі положення оскаржуються щодо їх відповідності принципу рівності. У 92 \% випадків рішення за процедурою оскарження грунтуються на висновку про невідповідність або часткове дотримання приниипу рівності. Водночас за результатами проведеного аналізу зроблено висновок, що найбільш суттєвою зміною стало поступове посилення контролю за дотриманням принципу рівності, навіть якщо Конституційна Рада відмовляється визнати його таким. Але це не заважало їи нав'язувати свою позиціо, коли че було необхідним для ефективного захисту основних прав і свобод, що в кінцевому рахунку могло бути запорукою успіху.

Ключові слова: Конституційна Рада Франції; попередній огляд; огляд після публікації; конкретний контроль; абстрактний контроль; методи конституційного контролю; конституційний блок; принцип рівності; самообмеження; захист основних прав і свобод.

Introduction. "They have an ardent, insatiable, eternal, invincible passion for equality; they want equality in liberty, and if they cannot obtain that, they still want equality in slavery". This is the way Alexis de Tocqueville presents the strong attachment of "democratic peoples" to the principle of equality in the famous chapter from the 1840 Democracy, by reference to French Revolution of $1789^{1}$. As Professor Maurice Hauriou pointed out, equality represented "the driving force in the Revolution" ${ }^{2}$. Besides its political symbol, this republican ideal defended by Jean-Jacques Rousseau ${ }^{3}$ in his major work The Social Contract, formed the basis of the process of building of modern French legal order and of the rule of law.

The first step in this process was marked by its introduction into the text of the Declaration of Human and Civic Rights of 26 August 1789, which main goal was to state a set of natural and inalienable rights that every individual could benefit ${ }^{4}$. Considering it as being "the most fundamental of the natural rights", the authors of the revolutionary text - Mirabeau, Mounier, Talleyrand, Sieyès, La Fayette have solemnly declared in article 1 that "Men are born and remain free and equal in rights". The requirement of equality is also provided for under articles 6 (equality in access to public employment) and 13 (equality before public charges) of the Declaration.

\footnotetext{
${ }^{1}$ A. De Tocqueville, De la démocratie en Amérique, vol. II, Paris, Garnier-Flammarion, 1981, p. 123.

${ }^{2}$ M. Hauriou, La science sociale traditionnelle, Paris, Larose, 1896, p. 80.

${ }^{3}$ Jean-Jacques Rousseau was the most popular philosopher among members of the Jacobin Club during the period of the French Revolution.

${ }^{4}$ For more information about the context of drafting of the Declaration of 1789, the issues and objectives of its authors, see G. Conac, M. Debène, G. Teboul (ed.), Déclaration des droits et l'homme et du citoyen de 1789. Histoire, analyses et commentaires, Paris, Economica, 1993, 365 p.

${ }^{5}$ The principle of equality was considered as more fundamental even than liberty itself, because "equality is man himself, it identifies man. In this sense, humanity itself is made up of a category of individuals of the same essence and so to deny equality is to reject humanity". Cf. G. Vedel, "L'égalité", in C. A. Colliard (ed.), La Déclaration des droits de l'homme et du citoyen de 1789. Ses origines, sa pérennité, Paris, La Documentation française, 1990, p. 171.
} 
Wishing to strengthen the irreversible nature of the "revolutionary gain", the constituent reaffirmed it in several paragraphs of the Preamble to the IV ${ }^{\text {th }}$ Republic Constitution of 27 October 1946: paragraph 1 (non-discrimination), paragraph 3 (equality between women and men), paragraph 11 (equality in the protection of health), paragraph 12 (equality before the charges resulting from national calamities), paragraph 13 (equal access to education), paragraph 16 (equality with the peoples of overseas) and paragraph 18 (equal access to public office for the peoples of overseas). The same approach can be noted in the Constitution of 4 October 1958, which is the founding text of the actual $\mathrm{V}^{\text {th }}$ Republic. The principle of equality is guaranteed in its Preamble (equality with the peoples of overseas), in article 1 (nondiscrimination), article 3 (equality of suffrage). The most symbolic is of course article 2, which includes it as an element of the motto of the French Republic: "Liberty, Equality, Fraternity".

Given the period of their drafting, these three constitutional texts are very different both by their philosophical inspiration and by their content, but they are really complementary. Since the famous decision of the Constitutional Council of 16 July 1971', they all form the so-called "constitutional block" (bloc de constitutionnalité) in relation to which the constitutional review is exercised in France $^{2}$. In this context, the principle of equality has its source in a set of at least fifteen articles guaranteeing the general principle of equality (such as the equality of everyone before the law) the sectorial principles of equality (before taxes, public services, suffrage) and the individual principles of equality (principle of nondiscrimination on the ground of sex, origin, religion) ${ }^{3}$.

This situation is incomparable with regard to other fundamental rights and freedoms which are mentioned only once in one of the three constitutional texts or then not at all, their guarantee having been progressively ensured thanks to evolving the Constitutional Council's case-law ${ }^{4}$. In view of these circumstances, many French

\footnotetext{
${ }^{1}$ CC, decision No. 71-44 DC of 16 July 1971, Law completing the provisions of articles 5 and 7 of the Law of 1 July 1901 on association agreements, available in English: https://www.conseilconstitutionnel.fr/en/decision/1971/7144DC.htm.

2 The Charter for the environment of 2004 was included in the "constitutional block" as the fourth text of reference. Its constitutional value has been expressly recognized in the Constitutional Council's decision No. 2008-564 DC of 19 June 2008.

${ }^{3}$ For a more detailed analysis on this subject, see O. Jouanjan, "Le Conseil constitutionnel, gardien de l'égalité ?", Jus Politicum, No. 7, 2012 : http://juspoliticum.com/article/Le-Conseil-constitutionnelgardien-de-l-egalite-459.html.

${ }^{4}$ In order to propose solutions in relation to a wider catalogue of rights and freedoms, the French Constitutional Council was inspired in particular from European Convention on Human Rights or the European Court of Human Rights' case-law. For example, it was the case of the right of private life respect, which is guaranteed by article 8 of the European Convention on Human Rights. In its decision of 23 July 1999, No. 99-416 DC, the Constitutional Council judged that it is a component of personal freedom guaranteed by the general provisions of article 2 of the 1789 Declaration. In the same way, the Constitutional Council asserted in the decision of 20 November 2003, No. 2003-484 DC, that the freedom of marriage, guaranteed by article 12 of the European Convention, must be considered as a component of personal freedom protected by articles 2 and 4 of the 1789 Declaration. The case-law of the Court of Strasbourg had a major impact on the development of judicial procedures,
} 
scholars asserted that the principle of equality must be considered as "the structuring principle of the Republic". Professor Dominique Rousseau² even called it "a central element of the constitutional identity of France"3. The Constitutional Council did not however follow his doctrinal position. In the decision n 2018-768 DC of 26 July 2018, French constitutional judges expressly stated that "this principle is also protected by European Union law, in particular by article 20 of the Charter of Fundamental Rights of the European Union”. Therefore, despite the very special place of this principle in French legal culture, it enjoys of an equivalent protection in European Union law and cannot be considered as an element of the constitutional identity of France exclusively.

This decision caused certainly some disappointment, but it was not really a surprise. First of all, the solution adopted by the Constitutional Council already appeared in the famous decision Sociüté Arcelor of the Council of State from 8 February 2007. We know that, in general, the jurisdictional positions between the two Councils are not very divergent. In its published commentary to the decision of 26 July 2018, the Constitutional Council explicitly refers to the aforementioned decision of the Council of State ${ }^{4}$. This clearly confirms the existence of a "dialogue of judges" on national level in order to preserve the principle of legal security. Secondly, this solution is in line with the general approach that the Constitutional Council adopted with regard to the principle of equality. In fact, the systematic analysis of its case-law shows that from 1973, when it first referred to the principle of equality ${ }^{5}$, to $1^{\text {st }}$ March 2010, date of the start of the implementation of the ex post review following the constitutional amendment of 23 July 2008, almost one decision in two includes statements relating to the compliance with this principle. Even if

in particular of criminal procedure. The Constitutional Council recognized, on the relatively tenuous basis of article 16 of the 1789 Declaration, a «right to an effective judicial remedy», which is directly inspired by article 6 of the Convention (CC, Decision No. 99-416 DC of 23 July 1999). Similarly, in the decision of 28 July 1989, No. 89-260 DC, the Constitutional Council decided that the principle of respect for the rights of the defence, which results from article 16 of the 1789 Declaration, "implies, in particular in criminal matters, the existence of a fair and equitable procedure guaranteeing the balance of the rights of parties". This solution stems from the cases Delcourt v. Belgium of 17 January 1970 and Golder v. the United Kigdom of 21 February 1975 relating to the right to a fair trial and to the equality of arms between parties.

${ }^{1}$ A. Levade, "Discrimination positive et principe d'égalité en droit français", Pouvoirs, No. 111, 2004, p. $55-71$.

${ }^{2}$ D. Rousseau, "Lidentité constitutionnelle, bouclier de l'identité nationale ou branche de l'étoile européenne?", in L. Burgorgue-Larsen (ed.), Lidentité constitutionnelle saisie par les juges en Europe, Pedone, Paris, 2011, p. 96.

${ }^{3}$ In France, the notion of "constitutional identity" was first formulated by the Constitutional Council in the decision No. 2006-540 DC of 27 July 2006, without defining it. Given the general nature of the formulation, it is generally considered that the main constitutional rules and principles can be inherent to this identity.

${ }^{4}$ Constitutional Council, «Commentaire. Décision n² 2018-786 DC du 26 juillet 2018, Loi relative a la protection du secret des affaires», available online: https://www.conseil-constitutionnel.fr/sites/ default/files/as/root/bank_mm/decisions/2018768dc/2018768dc_ccc.pdf.

${ }^{5}$ CC, decision No. 73-51 DC of 27 December 1973. 
developed well after administrative jurisprudence, the Council of State ${ }^{1}$ having first consecrated the principle of equality as a general principle of law in 1951 in its famous decision Sociüté des concerts du Conservatoire ${ }^{2}$, constitutional jurisprudence became gradually quite strong by confirming its constitutional nature and thereby strengthening its protection.

In the same time, the French constitutional judges' action was generally marked by self-limitation in this area. In 2010, when the ex post review began to be implemented in France - the so called procedure of $Q P C^{3}-$, many scholars invoked the possibility of a real change in the manner the Constitutional Council should use the techniques of control and, consequently, of an extension of the control it exercises in the field of the principle of equality ${ }^{4}$. Their assumptions are partially contradicted by the observed practice. The analysis of the $Q P C$ decisions referring to this principle highlights the same degree of discretion as in the ex ante review (I). The most significant change that can be noted is, in fact, the gradual strengthening of the concrete nature of the control that is exercised over compliance with the principle of equality even if Constitutional Council itself refuses to recognize it as such (II).

\section{The maintaining of the initially established cautious interpretation of the principle of equality.}

The French Constitutional Council's decisions are characterized by a fairly strict formalism and an uncommon concise drafting. Sometimes it is even necessary to read the official comment to the decision, that is written by the Council itself, to better understand the reasoning that led to the final solution. These technics are also used in the decisions relating to the control of compliance with the principle of

\footnotetext{
${ }^{1}$ In France, the Council of State (Conseil d'État) is the Supreme Court for administrative justice. The Court of Cassation (Cour de cassation) is the French Supreme Court for civil and criminal justice.

${ }^{2}$ The Council of State judged that: "Enshrined in law, administrative bodies do not have much possibility of modifying the application of the principle of equality. This explains why, except in the case of express legislative authorization, discrimination implemented by the administration can only be justified by a difference in situation in relation to the goal of the law to be carried out, or by considerations of public interest linked to the demands of public service" (CS, decision Société des concerts du Conservatoire, 9 March 1951).

${ }^{3}$ Provided for by article 61-1 of the Constitution, this procedure is called in France "Question prioritaire de constitutionnalité (QPC)". It can be initiated by anyone who is a party to a trial before a court of the judicial order or the administrative order if he/she considers that his/her rights and freedoms that the Constitution guarantees are infringed by the legislative provision applied in the litigation, whatever its nature (civil, criminal, fiscal, administrative, commercial, social, etc.). The question can be asked at first instance, on appeal or in cassation. If the conditions for admissibility of the question are met, it is up to the Constitutional Council, seized upon referral by the Council of State or the Court of Cassation, to rule and, if necessary, to repeal the legislative provision which is considered unconstitutional. For a detailed study in English of this procedure, see: F. Fabbrini, "Kelsen in Paris: France's Constitutional Reform and the Introduction of a Posteriori Constitutional Review of Legislation”, German Law Journal, vol. 9, No. 10, 2008, p. 1297-1312.

${ }^{4}$ F. Melun-Soucramanien, "Le principe d'égalité dans la jurisprudence du Conseil constitutionnel. Quelles perspectives pour la question prioritaire de constitutionnalité?", Cahiers du Conseil constitutionnel, No. 29, 2010, p. 89-100.
} 
equality, any methodological difference cannot therefore be noted. Such an approach allowed the Constitutional Council to develop a well-structured case-law, but which is marked by a voluntary self-restraint. The practice that was adopted within the framework of the ex ante review $(A)$ seems to remain the same in the $Q P C$ procedure $(B)$.

A. The establishment of a structured, but self-restraint case-law within the framework of the ex ante review.

During the first fifty years of its activity, the Constitutional Council never applied the principle of equality with the same intensity. In general, its interpretations depend on the context and the field of application of the legal provisions whose compliance with the Constitution is disputed. From the point of view of the intensity of the exercised control, three categories of interpretation can be distinguished:

- a rigorous interpretation accepting differences only if it is demonstrated that an imperative constitutional requirement involves modulation;

- an interpretation accepting modulations according to certain characteristics;

- a flexible interpretation accepting differences in treatment.

The rigorous interpretation is generally applied in the field of political rights. The only differences allowed by article 3 of the Constitution of 1958 relate to age, intellectual skills or certain criminal sentences ${ }^{1}$. The same approach is adopted in the area of criminal law and criminal procedure. The Constitutional Council admits with great reluctance the restrictions of the criminal procedure guarantees even in sensitive areas like the fight against terrorism ${ }^{2}$, even if a certain flexibility of interpretation can be observed since the terrorist attacks in Paris in 2015. In this special case, the constitutional review of national defence laws had become a delicate exercise for the Council face to the security policy of the legislator, whose action is widely approved by public opinion by claiming a fundamental right to security ${ }^{3}$.

In some special fields, the Constitutional Council judges that modulations must be made in order to reflect specific factors. For example, the level of taxes must be established according to the taxpayers' resources. The principle of progressive income tax has even received a constitutional value, it must rise with the ability to pay. The only imposed condition is that it must not be manifestly disproportionate ${ }^{4}$. In the same way, access to public employment may be subject to specific professional criteria: skills, virtues and talents. But these criteria must be respected and the legislator can add no other ones in the absence of a revision of the Constitution ${ }^{5}$. In fact, according to the French Constitutional Council's interpretation on this point, the constitutional principle of equality forbids the legislator from developing policies of positive discrimination. If such a measure is indisputably necessary, the only way

\footnotetext{
${ }^{1}$ CC, decision No. 82-146 DC of 18 November 1982; CC, decision No. 98-407 DC of 14 January 1999.

${ }^{2}$ CC, decision No. 93-326 DC of 11 August 1993; CC, decision No. 97-389 DC of 22 April 1997.

${ }^{3}$ For more details on this question, see K. Roudier, "Le Conseil constitutionnel face a l'avènement d'une politique sécuritaire", Les Nouveaux Cahiers du Conseil constitutionnel, No. 51, 2016, p. 37-50.

${ }^{4}$ CC, decision No. 93-320 DC of 21 June 1993.

${ }^{5}$ CC, decision No. 82-153 DC of 14 January 1983.
} 
out is to revise the Constitution. The inclusion in the text of the Constitution of a framework allowing positive discrimination is therefore analysed as an express consent given by the derived constituent to the legislator with a view to derogate from the principle of equality by establishing "compulsory program of preferential distribution of a benefit or service to a disadvantaged social group to compensate for social inequality"1.

Finally, in the third category of decisions, French constitutional judges use a flexible interpretation of the principle of equality accepting differences in treatment. This is in fact the vast majority of cases. A guideline recital is reiterated each time in cases relating to the introduction of differences of treatment and their control with regard to respect of the principle of equality: "The principle of equality does not preclude the legislator from treating different situations differently, or from derogating from equality on grounds of the general interest, provided always that the resultant difference of treatment is related to the object of the statute providing for it" . In the decision No. 97-388 DC of 20 March 1997, it was added that "the relationship with the object of the law" must be "direct".

It is important to note that the drafting of the recital used by the Constitutional Council while exercising the constitutional review in relation to the respect of the principle of equality was progressively developed. Its initial drafting was much more incomplete and general: "The principle of equality does not prevent the application of different rules to different situations"3. Through this change of content, the constitutional judges have set limits on the legislator's freedom of action. This technique is similar to that used by other constitutional jurisdictions, as for example the Belgian, Italian or German ones. At the same time, unlike these jurisdictions, and despite the symbolically strong place recognized to the principle of equality in French constitutional texts, the Constitutional Council often remains in the field of control of manifest error of assessment and is more hesitant when it comes to carrying out a control of proportionality on this question.

Two arguments can be put forward to explain this hesitation. The first one concerns the strong attachment of the French constitutional judges to respect the principle of separation of powers. The political reserve is therefore invoked each time when there is a risk to impinge on the Parliament's domain. This position also corresponds to the French legal history that is traditionally hostile to the limitation of parliamentary sovereignty, even if the logic of Rousseau that the law as the expression of the general will - may never be wrong, was exceeded with the introduction of the constitutional review by the Framers of the Constitution of 1958

\footnotetext{
${ }^{1}$ See on this point G. CALVÈS, "Les politiques de discriminations positives", Problèmes Politiques et Sociaux, No. 822, 1999, p. 5 .

${ }^{2}$ CC, decisions No. 87-232 DC of 7 January 1988; No. 89-266 DC of 9 January 1990; No. 90-280 DC of 6 December 1990; No. 90-283 DC of 8 January 1991; No. 91-291 DC of 6 May 1991; No. 91-296 DC of 29 July 1991; No. 92-316 DC of 20 January 1993; No. 94-348 DC of 3 August 1994; No. 95-369 DC of 28 December 1995; No. 96-377 DC of 16 July 1996.

${ }^{3}$ CC, decisions No. 81-129 DC of 30 and 31 October 1981; No. 85-189 DC of 17 July 1985; No. 86-217 DC of 18 September 1986.
} 
and with the position of the Constitutional Council itself, when it judged that "the law expresses the general will only if it respects the Constitution"'.

In fact, the doctrine of the French Constitutional Council on this point is absolutely different from that of the Constitutional Courts of Eastern European countries, for example. The latter consider that their role is to take action in order to solve all problems, especially the most questionable from a political point of view. They see in this action a condition of their legitimacy. On the contrary, according to the French Constitutional Council's doctrine, for theoretical as well as practical reasons, the self-limitation of the judge represents the golden rule of the constitutional litigation because it is the first condition of its legitimacy and its acceptance within the framework of a society based on the democratic principle. Since its decision of 15 January 1975, it reminded repeatedly that it does not have "the same discretionary power in the decision-making as the Parliament" ${ }^{2}$ In the field of the application of the principle of equality, this self-limitation is reinforced because as Professor Francisco Rubio Llorente pointed out, "the principle of equality constitutes the centre of tension between the legislator and the judge, between politics and Law, and therefore its application generates very frequently accusations of judicial activism or of the judge's abdication face to the legislator's arbitrariness"3. Knowing that a strict interpretation of the principle of equality by the constitutional judges can lead to the annulment of all legislator's choices when the law provides a different treatment for certain categories of persons, their caution can therefore appear as necessary in trying to find the right balance.

The second reason derives from the special nature of the ex ante review which was the only procedure of control that the French Constitutional Council could apply during the first fifty years of its activity. As such, it ruled on the constitutionality of the draft laws definitely adopted by the Parliament but not yet promulgated by the President. In the absence of any implementation, the Constitutional Council, like no other institution, cannot foresee all the effects that a draft law could produce with regard to the principle of equality and the $Q P C$ decision of 25 January $2019^{4}$, in which it noted the emergence in practice of a clear violation of the principle of equality, despite the "good intention" of the legislator to preserve health insurance finances ${ }^{5}$, is an example that perfectly illustrates the problem. In fact, as Professor W.A. Bogart noted in an important study on the

${ }^{1}$ CC, decision No. 85-197 DC of 23 August 1985.

${ }^{2}$ CC decision No. 74-54 DC of 15 January 1975.

${ }^{3}$ Cited by F. MELUN-SOUCRAMANIEN, op. cit. (n. 18).

${ }^{4}$ CC, decision No. 2018-757 QPC of 25 January 2019.

${ }^{5}$ The legislator established the principle according to which the transport of sick people was to be invoiced on the basis of "the cheapest transport". The problem that appeared was that the companies which had different types of transport had to invoice on this basis even when were used more expensive means of transport, like taxis. On the contrary, this obligation was not imposed to the companies which had only taxis because they were the only means of transport they had. Consequently, the former had to apply the cheapest rates each time, while it was not the case for the latter. There was clearly a breach of equality between these two categories of companies. 
impact of law ${ }^{1}$, the interaction of law with social, political and economic forces is a complicated process. What we know regarding it is "little more than guesswork bolstered by enticing theories" 2 . For defining the impact of a law on the respect of the equality principle, difficult questions are involved including the determination of causation and the assessment of existent outcomes. These elements are absent at the moment when the constitutional judges apply the ex ante review. That is why their margin of control is logically limited.

The introduction of the ex post review foresaw a change in the Constitutional Council's interpretation since it was going to be called upon to rule on a concrete situation of inequality which had appeared in practice. In the same time, the risk of confrontation with the legislator, as well as of disruption of the necessary security of the legal order, has increased. Being aware of the challenge, the French constitutional judges opted for the cautious solution that was well established in their practice.

B. The start of the change distorted by the resumption of the same control techniques within the framework of the ex post review.

The first $Q P C$ decisions seemed to define a new doctrine in the Constitutional Council's practice. In QPC No. 1 of 28 May 2010, it judged unconstitutional, on the basis of non-compliance with the principle of equality, several legislative provisions establishing a differentiation between the amounts of military pensions paid to French soldiers who fought for France and to nationals of countries and territories formerly under French sovereignty and, in particular, Algerian nationals ${ }^{3}$. The Constitutional Council proceeded to a careful analysis of all the legal situations established by the challenged legislative provisions before staying that the differentiation based on nationality criteria infringed article 6 of the Declaration of Human and Civic Rights of 1789.

A particular attention was also provided to the respect of the principle of equality in another very important $Q P C$ decision from 30 July 2010 on the French common police custody regime providing the modulation of the presence of the lawyer according to the nature of the offense $\mathrm{e}^{4}$. This was leading to the absence of a lawyer during the entire period of police custody, in particular during interrogations. Even if the existent regime has been, for many years, subject of questioning affecting both its principle and its methods, any legislative norm couldn't be challenged before the Constitutional Council because of the absence of the ex post review in France. A possible reform for remedying the dysfunctions observed in practice depended only on the will of the legislator. In these circumstances, it was not surprising that the non-compliance of the common police custody regime to the Constitution was one of the first questions submitted to the control of the Constitutional Council by French litigants. In an entirely unusual way from the point of view of their number,

\footnotetext{
${ }^{1}$ W.A. BOGART, "Introduction", in W.A. BOGART (ed.), Consequences: The Impact of Law and Its Complexity, University of Toronto Press, 2002, p. 3-20.

${ }^{2}$ Idem.

${ }^{3}$ CC, decision No. 2010-1 QPC of 28 May 2010.

${ }^{4}$ CC, decision No. 2010-14/22 QPC of 30 July 2010.
} 
thirty-six litigants invoked the non-compliance of this regime both with the rights of the defence and the principle of equality because of the established differentiation of treatment between the persons in custody. The Constitutional Council followed their line of reasoning and fixed to the legislator a deadline until the $1^{\text {st }}$ of July 2011 to adopt a new regime of common police custody ${ }^{1}$.

In the same way, by combining its control with regard to the respect of the principle of equality and the rights of the defence provided for in articles 6 and 16 of the Declaration of 1789, the Constitutional Council established within the framework of some $Q P C$ decisions the principle of balance of the rights of the parties in exercising their rights of appeal and to be assisted by a lawyer ${ }^{2}$. Through this requirement to balance the rights of the parties, the Council's case-law provided, in a relatively short time, a real constitutional framework to the criminal investigation procedure.

The new dynamic in the interpretation of the principle of equality was however short-lived. The Constitutional Council regained quite rapidly the control practices established within the framework of the ex ante review. One of the points of approach has been the acceptance in several $Q P C$ decisions dating from 2015 of derogations due to the objective of general interest pursued by the legislator. The general interest could have, for example, an incentive dimension in order to encourage a change of behaviour or an activity. In the QPC decision No. 2015-482 of 17 December 2015, the Council judged that the objective of the law was "to promote the recovery of waste by production of biogas" by setting up reduced tariffs for waste received by installations producing and recovering biogas. The difference in treatment between storage facilities of non-polluting waste, depending on whether or not they produce biogas, was directly related to this objective and could be considered as a general interest.

Similarly, in the $Q P C$ decision No. 2015-466 of 7 May 2015, the Council decided that the legislator, by granting a tax benefit to natural persons who didn't hold more than $25 \%$ of the rights in a young innovative company, aimed to support the private initiatives to participate to the development of these companies and contribute to their growth without nevertheless determining their decisions. It concluded that this objective was a goal of general interest justifying a difference in treatment between the partners of the young innovative companies according to their level of participation. Consequently, there was no infringement of the principle of equality. The Constitutional Council even referred to legislator's preparatory works in order to identify its intention to defend general interest by establishing tax deductions related to the sale of equity securities because it intended to maintain, for the sake

\footnotetext{
${ }^{1}$ The new law No. 2011-392 on the police custody was adopted on 14 April 2011. The Constitutional Council declared its compliance with the Constitution in decision No. 2011-191/194/195/196/197 QPC of 18 November 2011. It pronounced only one reserve of interpretation of the article 62 paragraph 2 of the Criminal Procedure Code.

2 CC, decisions No. 2010-15/23 QPC of 23 July 2010, No. 2010-81 QPC of 23 July 2010, No. 2011-153 QPC of 13 July 2011, No. 2011-160 QPC of 9 September 2011.
} 
of "loyalty" favourable to the taxpayers, the tax system previously applicable to transfers of equity securities issued in return for contributions made before they got to know the new measure ${ }^{1}$.

The objective of general interest has also been taken into account by the Constitutional Council in the cases it had a repressive or dissuasive dimension. In 2015, its case-law was marked by several decisions concerning fight against fraud and tax evasion. In all of them, constitutional judges upheld the constitutionality of the disputed laws ${ }^{2}$. They judged that the introduced differences in treatment were directly related to their object, which was to fight against tax optimization or tax evasion of companies carrying out investments or financial operations in non-cooperative States and territories. As usual, the Constitutional Council was self-limiting and refused to control extensively the goals that the legislator has set for itself. In its practice, this kind of differentiations of treatment led to annulments very rarely.

The tax law is not the only field in which such an approach was chosen by French constitutional judges. The basis they used for justifying the legislator's decisions varied between the "general interest", the "imperative general interest"3, or the absence of an "excessive impingement". For this last case, the Constitutional Council exercised a control of proportionality, a quite rare practice in controlling the respect of the principle of equality, but it came up with a solution opposite to that adopted by the German Constitutional Court on the same question. In fact, in the QPC decision No. 2019-811 of 25 October 2019, the authors of the request (members of a new political party) challenged the constitutionality of the established threshold of $5 \%$, which must be reached by a list for accessing the distribution of seats in the European Parliament. They took up all the arguments that the German Constitutional Court invoked in order to cancel, first in 2011, the 5\% threshold and then, in 2014, the 3\% threshold established for the same elections. The French Council refused to follow this reasoning and judged that the 5\% threshold was introduced in order to "avoid a fragmentation of representation which would impact the good functioning of the European Parliament”. Such a system allows to strengthen the influence of the main political currents expressed in France within the European Parliament. Consequently, knowing the objective pursued by the legislator, the model that it chose had not to be considered as a disproportionately violation both of the principle of equality and the principle of political pluralism. Besides the opposite nature of its decision, we can also see that the Constitutional Council didn't take into account the concrete situation of the author of the request, as the fact that it was a new political party and then it could not have the same political coverage than a traditional political party. It realized an abstract control only, outside of any contextual element, when we know that taking into account concrete contextual elements leads the constitutional judges to exercise a much more exhaustive control. This is another substantive issue of dispute in France that we'll analyse bellow.

\footnotetext{
${ }^{1}$ CC, decision No. 2015-475 QPC of 17 July 2015.

${ }^{2}$ CC, decisions No. 2014-437 QPC of 20 January 2015, No. 2015-473 QPC of 26 June 2015.

${ }^{3}$ CC, decision No. 2019-776 QPC of 20 April 2019.
} 


\section{The gradual establishment of an unacknowledged concrete control.}

When the ex post review was introduced in France, several authors used the terms of "concrete review" for qualifying the $Q P C$ procedure $^{1}$. However, the Constitutional Council quickly affirmed that the exercised control within the framework of the new procedure had to remain abstract. In other words, it must rest devoid of any influence of the elements of the litigation within the framework of which the question of constitutionality is raised. After ten years of implementation of the $Q P C$ procedure, it can be noted that this common vision of French constitutional justice defended by the Constitutional Council is confronted with jurisdictional realism, which is inherent in the application of the Constitution and the control of its respect. If the control techniques borrow largely from those used within the framework of the ex ante review, the concretization movement is inevitable in the $Q P C$ procedure (A). This appears even more clearly in the case-law relating to the principle of equality (B).

A) The inevitable concretization of the control in the QPC procedure.

First of all, as a preliminary point, it should be noted that the debate that exists in France concerning the exercise or not of a concrete control by the Constitutional Council within the framework of the procedure of $Q P C$ is rather exceptional. It can even seem stripped of meaning with regard to the very clear position of the constitutional judges of other European countries. Certainly, the doctrinal definitions of concrete and abstract control are quite diverse but they partially overlap with a few determining elements. Overall, scholars agree that abstract control is characterized by the fact that it is not initiated on the occasion of a dispute before an ordinary court but on the initiative of a public authority, which is acting in order to defend a general interest. Its object is either the resolution of a conflict of legal norms in order to ensure a permanent constitutional supremacy or a conflict of competency between constitutional institutions. This type of control is closely inspired by Kelsen's theory on negative legislator. On the contrary, concrete control is initiated by the litigant who is directly concerned by the application of a legal norm during a litigation. Its main purpose is to preserve the litigant's subjective rights. In this case, the control can be exercised only a posteriori, while the abstract control is possible both in a priori or a posteriori constitutional review ${ }^{2}$.

As we can see, these procedural elements lead to the establishment of a strict delimitation of the two types of control that is perfectly clear. Some Constitutional Courts, as it is the case in Russian Federation, choose to apply it in practice in order to better manage the flow of the constitutional complaints presented by litigants. The said elements are used as admissibility criteria, the litigants having the right

\footnotetext{
${ }^{1}$ O. Pfersmann, "Le renvoi préjudiciel sur exception d'inconstitutionnalité: la nouvelle procédure de contrôle concret a posteriori", Petites affiches, No. 254, 2008, p. 103; D. Rousseau, "La question prioritaire de constitutionnalité: un big-bang juridictionnel?”, RDP, No. 3, 2009, p. 631; R. Fraisse, "QPC et interprétation de la loi", Petites affiches, No. 89, 2011, p. 5.

${ }^{2}$ C. Grewe, "Le contrôle de constitutionnalité de la loi en Allemagne : quelques comparaisons avec le système français", Pouvoirs, No. 137, 2011, p. 143; M. Fromont, La justice constitutionnelle dans le monde, Paris, Dalloz, 1996, p. 41 et s.
} 
to initiate only a control of the application that was made of a legal norm but not of its content in general ${ }^{1}$. In contrast, the position of the Belgian Constitutional Court seems closer to a more flexible practical application of the distinction between the two types of control. This choice aligns with the opinion of a second group of scholars who consider that the distinction between abstract and concrete control is largely based on the importance that judges will give to factual considerations while exercising the constitutional review ${ }^{2}$. By adopting this approach, Belgian constitutional judges agree to exercise - if the context of the case requires such an approach - both a concrete control in order to guarantee the respect of the litigant's subjective rights and an abstract control for ensuring that the controlled legal norm does not contain other unconstitutionalities, even if the request is initiated by a litigant $^{3}$. In fact, the requirement to judge includes the obligation to give adequate reasons for the decisions that are pronounced. Sometimes, when constitutional judges engage in a concrete control, they may consider useful, even essential, to justify beforehand the constitutionality of the legal norm envisaged in abstracto, as shown by a very well-known decision of the Belgian Constitutional Court on the rules relating to the prohibition of marriage between step-parents and stepchildren ${ }^{4}$.

If we analyse the procedure of $Q P C$ introduced in France by opposing the determining elements of delimitation between concrete and abstract control, it appears quite obvious that the control exercised by the Constitutional Council cannot be deprived of concrete character. First of all, the procedure of $Q P C$ is marked by the existence of a concrete situation from which the question of constitutionality emerged. It arises from an existent dispute before the ordinary courts. As Professor Dominique Rousseau said, "constitutional litigation is the necessary continuity of ordinary litigation"5.

In fact, the Constitutional Council is only seized by the litigant's conclusions. It cannot be seized ex officio by ordinary judges. Following the generally implemented method in the European Constitutional Courts' practice, the decisions pronounced by French constitutional judges are named after the litigants. Their representatives present, in a public audience, the concrete situation that is at the origin of the $e x$

\footnotetext{
${ }^{1}$ See, for example, the decisions of the Russian Constitutional Court No. 2542-O of 23 November 2017 and No. 2931-O-P of 26 November 2018.

${ }^{2}$ J. Pini, Recherches sur le contentieux de constitutionnalité, Puam, 1997, p. 329; G. Drago, Contentieux constitutionnel français, Puf, 2011, p. 41-42; J.-H. Stahl \& C. Maugüe, La question prioritaire de constitutionnalité, Dalloz, 2011, p. 7.

${ }^{3}$ M. Verdussen, "La Cour constitutionnelle belge exerce-t-elle un contrôle concret?", Annuaire international de justice constitutionnelle, vol. 29, 2014, p. 17-23.

${ }^{4}$ Decision No. 157/2006 of 18 October 2006 (In this decision, the Constitutional Court first legitimized in general terms, by exercising an abstract control, the prohibition of the incest and consequently the constitutionality of article 164 of Civil Code. Then, by carrying out a concrete control of this article, it judged that there was violation of articles 10 and 11 of the Constitution by the absolute marriage prohibition between a step-parent and a stepchild. This prohibition has disproportionate consequences in that it prohibits in all cases the marriage of a stepparent and stepchild after the decease of the spouse who created the family relationship).

${ }^{5}$ D. Rousseau, "Le procès constitutionnel”, Pouvoirs, No. 137, 2011, p. 49.
} 
post review in order to respect the right to a fair trial guaranteed by article 6 of the European Convention on Human Rights. If the facts of the litigation involve the organisation of a closed audience or if the litigant makes a specific request to protect his private life, the President of the Constitutional Council may order it in accordance with article 8 of the Rules of Procedure of QPC of 18 February 2010. So, as Marthe Farin-Rouge Stefanini noted in several studies on this question ${ }^{1}$, even if the facts of the litigation are not indicated in the decision of the French Constitutional Council, contrary to what can be found in Belgium, Spain or Italy, all the above mentioned stages of the procedure of $Q P C$, as well as the working methods that are implemented since the decision is adopted, have necessarily a psychological impact on the constitutional judges. They cannot completely ignore the concrete facts of the initial litigation and limit their control to the content of the legal norm for safeguarding its objective aspects while the request of the litigant relates to his subjective situation.

In addition, French litigants cannot seize the Constitutional Council if it has already pronounced a decision on the compliance with the Constitution of a legislative provision they want to challenge. In the case when such a decision exists, they have to prove that, in their case, there is a change of circumstances. This change may occur from the point of view of law or in fact. In such cases, it is undeniable that the Constitutional Council cannot ignore the concrete situation of the litigant. It is a very important element because, on the one hand, it determines the effectiveness of the $Q P C$ procedure and, on the other hand, it guarantees the balance between respect for legal security and the constitutional rights and freedoms ${ }^{2}$.

French litigants have also the right to challenge a constant jurisprudential interpretation of a legislative provision. This right was explicitly established by the Constitutional Council in the QPC decision No. 2010-39 QPC of 6 October 2010, by following the example of the Italian Constitutional Court which did this in the decision No. 3 of 15 June 1956. So, French constitutional judges accepted the implementation of the Italian "living law" doctrine. The $Q P C$ procedure is not reasonably confined to an assessment of the legislative provision alone. The Council rules on the constitutionality of the effective scope of the provision, its concrete scope. In this case too, it is difficult to assert that the constitutional review remains abstract.

Finally, the concretization of the control is revealed in the effects that are attached to the $Q P C$ decisions. Article 62 of the Constitution states that within the framework of the ex post review, a provision that is declared unconstitutional is repealed from the date of the publication of the Constitutional Council's decision or at a later date that

\footnotetext{
${ }^{1}$ M. Fatin-Rouge Stefanini, "La singulariré du contrôle exercé a posteriori par le Conseil constitutionnel: la part du concret et la part d'abstrait”, Les Nouveaux cahiers du Conseil constitutionnel, No. 38, 2013, p. 211; M. Fatin-Rouge Stefanini, "Les effets des décisions du Conseil constitutionnel en matière de QPC", in N. Danelciuc-Colodrovschi (ed.), Évolutions et limites du contrôle de constitutionnalité. Regards croisés entre les expériences française et est-européennes, Puam, 2018, p. 61-73.

${ }^{2}$ CC, decisions No. 2010-14/22 QPC of 30 July 2010, No. 2011-125 QPC of 6 May 2011, No. 2012233 QPC of 21 February 2012, No. 2013-331 QPC of 5 July 2013.
} 
is determined by the said decision. The constitutional judges have the possibility to modulate the effects of their decisions in order to preserve the legal security and to allow the necessary time to the legislator for doing the required legislative changes. In the same time, the deferral to a later date of the effects of a decision will deprive the author of the request from benefiting of its effects. In order to ensure the useful effects of the pronounced $Q P C$ decisions, the Constitutional Council pays much attention to the situation of the litigant who challenged the unconstitutional legislative provisions and that of other litigants who are in the same case. This principle was established from the first $Q P C$ decision ${ }^{1}$ and underlines the impact of the facts on the control that is exercised by the French constitutional judges.

The concretization of the control aims to allow better effectiveness of the fundamental rights by responding practically on a case-by-case basis to the encountered situations. The concrete dimension of this control is accentuated regarding the respect of the principle of equality because they deal with situations that reveal not only unconstitutionality but also a form of injustice that the legislator had not imagined and that the judge must stop as quickly as possible.

$B$ ) The acceleration of the concretization of the control by guaranteeing the principle of equality.

On 31 May 2017, the Constitutional Council rendered a very important decision following the request presented by the political party En Marche! created by President Emmanuel Macron ${ }^{2}$. The party raised the unconstitutionality of article L. 167-1 of the Electoral Code that provided for all political parties an airtime in order to promote the electoral campaign in function of results obtained in the last elections for the National Assembly. The party En Marche! had just been created and had never participated in elections. Consequently, it had almost no airtime. The Constitutional Council was called to appreciate the compliance of this article with the principle of equality before the suffrage and with the principle of equality before the law.

This decision is important not only from the point of view of its issue, as regards in particular the guarantee of political pluralism, which is an inherent condition for building and safeguarding a democratic regime. It represents a scholar case of concretization of the control that is exercised by the constitutional judges. The concrete dimension seems to be triple in this case. First of all, the decision of unconstitutionality could only be supported by the concrete circumstances, namely those of a new party represented by the President of the Republic who had just been elected and who needed a majority in the National Assembly in order to realize its political program. Secondly, the Constitutional Council anticipated the concrete consequences of its declaration of unconstitutionality. Considering that such a declaration would have had the effect of "removing all legal basis for the determination by the Superior council of audio-visual (...) of the durations of the emissions of the electoral campaign for the legislative elections", it has postponed to 30 June 2018 the date of effect of the repeal. Thirdly, in order to enable the

\footnotetext{
${ }^{1}$ CC, decision No. 2010-1 QPC of 28 May 2010.

${ }^{2}$ CC, decision No. 2017-651 QPC of 31 May 2017.
} 
political party En Marche! to benefit from the decision of unconstitutionality, and therefore to benefit from its useful effect, the Constitutional Council defined itself a legal framework in conformity with the Constitution, aiming, in an extremely concrete way, the case of the said political party. It ruled that for the 2017 legislative elections, the article L.167-1 of the Electoral Code should be applied by taking into account the importance of the new political party, the number of candidates who declare to be attached to it and their representativeness, appreciated in particular by reference to the results obtained during other previous elections, such as European, local or presidential ones. The Constitutional Council judged that it was the only condition to ensure equal participation of the new political parties or movements in democratic life and to guarantee the respect of the political pluralism. In this decision, the entire reasoning of the judges is based on the control of proportionality of the factual elements with regard to the principle of equality and we can see that this technique of control allows them to exercise a more extensive control than in the cases when they do it with regard to the intention of the legislator or to the general interest. As we could see above, this second approach, which excludes concrete control, leads finally to a more restrictive interpretation.

The question of the choice between the two approaches arises regularly in the field of tax law. More specifically, tax litigations have always been the privileged field for invoking the principle of equality. This observation is confirmed, even amplified, since the introduction of the $Q P C$ procedure. According to statistical data, in $73 \%$ of the requests received by the Constitutional Council, the legislative provisions are challenged with regard to their compliance with the principle of equality. In $92 \%$ of cases, the $Q P C$ decisions of unconstitutionality or partial constitutionality in the field of tax law are based on the conclusion of non-compliance with the principle of equality. The consequences of these cancellations are very significant, particularly in terms of maintaining a balanced and fair tax system. This is probably the reason explaining the frequent use by the constitutional judges of the technique of reserve of interpretation in the $Q P C$ decisions relating to the tax law. For example, during the period from 2016 to 2018, the challenged legislative provisions were declared unconstitutional or partially constitutional in $27 \%$ of cases. At the same time, a quarter of the decisions of constitutionality contain reservations of interpretation.

This technique of control used firstly in a decision of $1959^{1}$, allows maintaining of the challenged legislative provisions in the national legal order under the condition they are interpreted in the way the Constitutional Council decided in its decisions. It constitutes a "rescue" procedure by which the constitutional judges do not get stuck in a binary choice between the censure of the law and the rejection of the request. The reserve of interpretation often settles very important points of law and has two major advantages. From the legal point of view, it contributes to the guarantee of the legal security as it settles questions of application of the law, which are of a constitutional nature and have the effect of res judicata. On the political level, the technique of reservation of interpretation allows to avoid an excessively

${ }^{1}$ CC, decision No. 59-2 DC of 24 June 1959. 
brutal conflict with the Government and with the majority of the Parliament that voted for the law, while giving satisfaction to the seizers who criticize it.

In the practice of the French Constitutional Council, three types of reserves of interpretation can be distinguished:

- neutralizing reserves, which eliminate possible interpretations that would be contrary to the Constitution;

- guideline reserves, which include a requirement for the legislator or a law enforcement authority;

- constructive reserves, when the Council makes additions to the law in order to bring it into conformity with the Constitution.

Since the entry into force of the $Q P C$ procedure, the Constitutional Council maintains the consistency of its case-law on the main points of control of tax law. Continuity is evident in the application of the principle of equality before taxes guaranteed by article 13 of the 1789 Declaration. In its decisions, it reminds each time that the taxpayers' situation has to be assessed with regard to each tax separately ${ }^{1}$. As for the respect of the principle of equality before the law, that is guaranteed by article 6 of the same Declaration, it verifies whether the criteria implemented by the legislator are objective and rational and whether they are related to the object of the measure and the aim pursued or to the differences in situation taken into account. Finally, it censures the marked breaks in equality before public charges. By using the technique of reserve of interpretation, the Constitutional Council verifies if these two principles are respected with regard to the concrete situation of the litigant who submitted the request and if the challenged legislative provisions lead to a "marked breach of equality before public charges". So, in this case again, we have a piece of evidence of the concretization of the control that is exercised by the Constitutional Council.

We'll take for analysis two $Q P C$ decisions, which are quite emblematic on this question. The first one is a decision of 21 January 20112. The Constitutional Council was asked to appreciate the compliance with the Constitution of article 168 of the Tax Code providing the possibility of taxation on the basis of a scale applied to certain elements of the taxpayer's lifestyle. It's the case of automatic taxation that can be imputed by tax administration in the light of "external signs of richness" revealing that the taxpayers lead a lifestyle that does not correspond to the income they declared and if the threshold exceeds the sum of 40,000 euros. The Constitutional Council validated the paragraph 1 of the challenged article considering that there was no violation of the principle of equality before law and public charges, as it was asserted by the litigant. It is related to the object of the measure and the aim pursued by legislator in fighting against fraud and tax evasion in the general interest. The paragraph 2 of the said article, which provided for a $50 \%$ increase in the tax scale if the value of the goods considered as undeclared was greater than 80,000 euros, was however declared unconstitutional because of its non-

${ }^{1}$ CC, decision No. 2010-28 QPC of 17 September 2010.

${ }^{2}$ CC, decision No. 2010-88 QPC of 21 January 2011. 
compliance with the principle of equality before public charges. The $Q P C$ decision contains also a reserve of interpretation concerning the respect of contradictory principle. The Constitutional Council recognized that the litigant hadn't had any possibility to prove that the financing of his heritage goods did not imply the possession of incomes defined on a lump sum basis. The determination of the tax base must however be considered as part of a contradictory procedure in order to allow the taxpayers to effectively defend their fundamental rights.

In the $Q P C$ decision of 4 December 2015 concerning the fiscal solidarity between spouses, the Constitutional Council used the same method of constructive reserve of interpretation ${ }^{1}$. In French law, fiscal solidarity continues during the divorce proceedings, after the divorce and in the event of the breakdown of common life, if there are sums to be paid under common taxation. Thus, each of the spouses can be called to pay the total amount of the common taxation, without there being any need to proceed to a prior distribution of the tax debt. Consequently, the administration can prosecute either of the spouses for the recovery of all of the said income tax. In addition, the special agreements resulting from a divorce judgment regarding the distribution of the burden of these taxes cannot be opposed to it. In its decision, the Council judged that there was no problem of constitutionality because of the fact that the principle of irrefragable presumption is opposed to the two spouses after their separation for the common declarations of the income tax. Nevertheless, the constitutional judges ruled that when two persons, previously under common taxation, are subject to separate taxation on the date of notification of the assessment of additional taxes established on the income received during the period of joint taxation, the irrefragable presumption can prevent the spouse with whom the procedure was not followed from making a contentious claim, which is the first step in tax litigation. This problem is all the more evident when the two spouses live at different addresses, as it was the case of the litigants who initiated the present $Q P C$ procedure, and they informed tax administration of these changes. Henceforth, the right to an effective legal remedy is not guaranteed. The Constitutional Council made a reserve of interpretation in order to prevent such infringement by staying that, in this concrete situation, the assessment of additional taxes has to be notified to both spouses. Moreover, as it ruled in several QPC decisions of 2016 and 20172, in the case the reserves of interpretation present difficulties of interpretation in a given situation, it may be seized for a new $Q P C$ procedure. This is further proof that it is impossible to disregard any concrete element while exercising ex post review, especially in certain areas, which particularly affect the litigants' personal situation. The introduction of the $Q P C$ procedure leads to an increased jurisdictionalization of the Constitutional Council in its role of judge of the tax law. This will probably lead it to take more into account than in the past the case-law of the Court of Strasbourg which control is of concrete nature only.

\footnotetext{
${ }^{1}$ CC, decision No. 2015-503 QPC of 4 December 2015.

${ }^{2}$ CC, decisions No. 2016-538 QPC of 22 April 2016, No. 2016-610 QPC of 10 February 2017, No. 2017-643/650 QPC of 7 July 2017.
} 
In the context of this study, we have noted the presence of a certain number of inconsistencies. Many points should be improved so that the Constitutional Council strengthens its place as the German, Italian or Belgian Constitutional Courts did at specific moments of their history. However, the caution that we have underlined several times, even if it may seem confusing, has proven its effectiveness. The French Constitutional Council has gradually evolved from its original status of "watchdog of the executive power", whose role was to supervise the action of the Parliament, to that of guardian of the Constitution. The introduction of the $Q P C$ procedure was an additional step in the assertion of its legitimacy as such. It is absolutely sure that revolutionary blows have rarely been part of the French Constitutional Council's activity, but progress has been continuous, a fact that calls to mind the widely known saying "Who goes slowly surely goes". In increasingly complex political, economic and social contexts both on national and international levels, this could ultimately be the key to success.

Conclusion. This study revealed several important points. From the statistical point of view, the principle of equality occupies much more important place within the framework of the ex post review than that noted before its introduction. In some special fields, like tax law, in $73 \%$ of the requests received by the Constitutional Council, the legislative provisions are challenged with regard to their compliance with the principle of equality. In $92 \%$ of cases, the $Q P C$ decisions in this field are based on the conclusion of non-compliance or partial compliance with the principle of equality. In the same time, the realized analysis highlight the same degree of discretion of the constitutional judges' control as in the ex ante review. The most significant change that can be noted is, in fact, the gradual strengthening of the concrete nature of the control that is exercised over compliance with the principle of equality even if Constitutional Council itself refuses to recognize it as such. In the same time, throughout this study, we could see that it has always acted with caution. This did not prevent it from imposing its position when it considered essential for the effective protection of the fundamental rights and freedoms. In increasingly complex political, economic and social contexts both on national and international levels, this could ultimately be the key to success.

\section{References}

1. De Tocqueville, De la démocratie en Amérique, vol. II, Paris, Garnier-Flammarion, 1981, p. 123.

2. M. Hauriou, La science sociale traditionnelle, Paris, Larose, 1896, p. 80.

3. Jean-Jacques Rousseau was the most popular philosopher among members of the Jacobin Club during the period of the French Revolution.

4. G. Conac, M. Debène, G. Teboul (ed.), Déclaration des droits et l'homme et du citoyen de 1789. Histoire, analyses et commentaires, Paris, Economica, 1993, 365 p.

5. G. Vedel, "Légalité", in C. A. Colliard (ed.), La Déclaration des droits de l'homme et du citoyen de 1789. Ses origines, sa pérennité, Paris, La Documentation française, 1990, p. 171.

6. Constitutional Council, decision No. 71-44 DC of 16 July 1971, Law completing the provisions of articles 5 and 7 of the Law of 1 July 1901 on association agreements, available in English: https:// www.conseil-constitutionnel.fr/en/decision/1971/7144DC.htm.

7. Constitutional Council's decision No. 2008-564 DC of 19 June 2008.

8. O. Jouanjan, “Le Conseil constitutionnel, gardien de l'égalité?", Jus Politicum, No. 7, 2012, available online: http://juspoliticum.com/article/Le-Conseil-constitutionnel-gardien-de-l-egalite-459.html. 
9. Constitutional Council, Decision No. 99-416 DC of 23 July 1999).

10. Levade, "Discrimination positive et principe d'égalité en droit français", Pouvoirs, No. 111, 2004, p. $55-71$.

11. D. Rousseau, "L’identité constitutionnelle, bouclier de l'identité nationale ou branche de l'étoile européenne?”, in L. Burgorgue-larsen (ed.), Lidentité constitutionnelle saisie par les juges en Europe, Pedone, Paris, 2011, p. 96.

12. Constitutional Council, «Commentaire. Décision n 2018-786 DC du 26 juillet 2018, Loi relative a la protection du secret des affaires», available online: https://www.conseil-constitutionnel.fr/ sites/default/files/as/root/bank_mm/decisions/2018768dc/2018768dc_ccc.pdf.

13. Constitutional Council, decision No. 73-51 DC of 27 December 1973.

14. Council of State, decision Société des concerts du Conservatoire, 9 March 1951.

15. F. Fabbrini, "Kelsen in Paris: France's Constitutional Reform and the Introduction of a Posteriori Constitutional Review of Legislation”, German Law Journal, vol. 9, No. 10, 2008, p. 1297-1312.

16. F. Melun-Soucramanien, "Le principe d'égalité dans la jurisprudence du Conseil constitutionnel. Quelles perspectives pour la question prioritaire de constitutionnalité?", Cahiers du Conseil constitutionnel, No. 29, 2010, p. 89-100.

17. Constitutional Council, decision No. 82-146 DC of 18 November 1982.

18. Constitutional Council, decision No. 98-407 DC of 14 January 1999.

19. Constitutional Council, decision No. 93-326 DC of 11 August 1993

20. Constitutional Council, decision No. 97-389 DC of 22 April 1997.

21. Roudier, "Le Conseil constitutionnel face a l'avènement d'une politique sécuritaire", Les Nouveaux Cahiers du Conseil constitutionnel, No. 51, 2016, p. 37-50.

22. Constitutional Council, decision No. 93-320 DC of 21 June 1993.

23. Constitutional Council, decision No. 82-153 DC of 14 January 1983.

24. G. Calvès, "Les politiques de discriminations positives", Problumes Politiques et Sociaux, No. 822, 1999, p. 5 .

25. Constitutional Council, decisions No. 87-232 DC of 7 January 1988; No. 89-266 DC of 9 January 1990; No. 90-280 DC of 6 December 1990; No. 90-283 DC of 8 January 1991; No. 91-291 DC of 6 May 1991; No. 91-296 DC of 29 July 1991; No. 92-316 DC of 20 January 1993; No. 94-348 DC of 3 August 1994; No. 95-369 DC of 28 December 1995; No. 96-377 DC of 16 July 1996.

26. Constitutional Council, decisions No. 81-129 DC of 30 and 31 October 1981; No. 85-189 DC of 17 July 1985; No. 86-217 DC of 18 September 1986.

27. Constitutional Council, decision No. 85-197 DC of 23 August 1985.

28. Constitutional Council, decision No. 74-54 DC of 15 January 1975.

29. Constitutional Council, decision No. 2018-757 QPC of 25 January 2019.

30. W.A. Bogart, "Introduction", in W.A. BOGART (ed.), Consequences: The Impact of Law and Its Complexity, University of Toronto Press, 2002, p. 3-20.

31. Constitutional Council, decision No. 2010-1 QPC of 28 May 2010.

32. Constitutional Council, decision No. 2010-14/22 QPC of 30 July 2010.

33. Constitutional Council, decisions No. 2010-15/23 QPC of 23 July 2010; No. 2010-81 QPC of 23 July 2010; No. 2011-153 QPC of 13 July 2011; No. 2011-160 QPC of 9 September 2011.

34. Constitutional Council, decision No. 2015-475 QPC of 17 July 2015.

35. Constitutional Council, decisions No. 2014-437 QPC of 20 January 2015; No. 2015-473 QPC of 26 June 2015.

36. Constitutional Council, decision No. 2019-776 QPC of 20 April 2019.

37. O. Pfersmann, "Le renvoi préjudiciel sur exception d'inconstitutionnalité: la nouvelle procédure de contrôle concret a posteriori”, Petites affiches, No. 254, 2008, p. 103;

38. D. Rousseau, "La question prioritaire de constitutionnalité: un big-bang juridictionnel?", $R D P$, No. 3, 2009, p. 631;

39. R. Fraisse, “QPC et interprütation de la loi”, Petites affiches, No. 89, 2011, p. 5.

40. Grewe, "Le contrôle de constitutionnalité de la loi en Allemagne: quelques comparaisons avec le système français", Pouvoirs, No. 137, 2011, p. 143;

41. M. Fromont, La justice constitutionnelle dans le monde, Paris, Dalloz, 1996, p. 41. 
42. Decisions of the Russian Constitutional Court No. 2542-O of 23 November 2017 and No. 2931-O-P of 26 November 2018.

43. J. Pini, Recherches sur le contentieux de constitutionnalité, PUAM, 1997, p. 329;

44. G. Drago, Contentieux constitutionnel français, PUF, 2011, p. 41-42.

45. J.-H. Stahl \& C. Maugüe, La question prioritaire de constitutionnalité, Dalloz, 2011, p. 7.

46. M. Verdussen, "La Cour constitutionnelle belge exerce-t-elle un contrôle concret?", Annuaire international de justice constitutionnelle, vol. 29, 2014, p. 17-23.

47. Rousseau, "Le procès constitutionnel", Pouvoirs, No. 137, 2011, p. 49.

48. M. Fatin-Rouge Stefanini, "La singulariré du contrôle exercé a posteriori par le Conseil constitutionnel: la part du concret et la part d'abstrait", Les Nouveaux cahiers du Conseil constitutionnel, No. 38, 2013, p. 211;

49. M. Fatin-Rouge Stefanini, "Les effets des décisions du Conseil constitutionnel en matière de QPC", in N. Danelciuc-Colodrovschi (ed.), Évolutions et limites du contrôle de constitutionnalité. Regards croisés entre les expériences française et est-européennes, PUAM, 2018, p. 61-73.

50. Constitutional Council, decisions No. 2010-14/22 QPC of 30 July 2010; No. 2011-125 QPC of 6 May 2011; No. 2012-233 QPC of 21 February 2012; No. 2013-331 QPC of 5 July 2013.

51. Constitutional Council, decision No. 2010-1 QPC of 28 May 2010.

52. Constitutional Council, decision No. 2017-651 QPC of 31 May 2017.

53. Constitutional Council, decision No. 59-2 DC of 24 June 1959.

54. Constitutional Council, decision No. 2010-28 QPC of 17 September 2010.

55. Constitutional Council, decision No. 2010-88 QPC of 21 January 2011.

56. Constitutional Council, decision No. 2015-503 QPC of 4 December 2015.

57. Constitutional Council, decisions No. 2016-538 QPC of 22 April 2016; No. 2016-610 QPC of 10 February 2017; No. 2017-643/650 QPC of 7 July 2017.

Данельчук-Колодровски Н., доктор права, научный сотрудник, Университет Экс Марсель, Университет Тулона, Университет По э де Пеи де Л’Адур, CNRS, DICE, ILF, Франция, Экс-ан-Прованс.

e-mail: natasa.colodrovschi-danelciuc@univ-amu.fr

Принцип равенства в прецедентном праве Конституционного Совета Франции: что изменятся спустя десять лет фактического применения?

Во Франиии принии равенства основан на не менее чем пятнадиати статьях, относящихся $\kappa$ одному из трех конституционных текстов, которые составляют «конституционный блок». Из-за этого привилегированного места, которое несопоставимо с другими основными правами $и$ свободами, принщип равенства фигурировал почти в половине решений, вынесенных Конституционным Советом с момента его создания до 2010 г., когда пересмотр ех post - так называемая «процедура QPC» - начали внедряться во Франщии. Несмотря на соответствующие статистические данные, деятельность конституционных судей в этой области была отмечена добровольным сдержанием. Целью данного исследования является анализ того, изменился ли их подход в первые десять лет внедрения процедуры QPC для усиления защиты прав сторон и какие методы контроля они используют для реализащии таких изменений.

Ключевые слова: Конституционный Совет Франции; предварительный обзор; обзор после публикации; конкретный контроль; абстрактный контроль; методы конституционного контроля; конституционный блок; принцип равенства; самоограничение; защита основных прав и свобод.

Рекомендоване цитування: Danelciuc-Colodrovschi N. The principle of equality in the French Constitutional Council's case-law: what changes after ten years of ex post review implementation? Проблеми законності. 2020. Вип. 150. С. 292-312. doi: https://doi.org/10.21564/2414-990x.150.206778.

Suggested Citation: Danelciuc-Colodrovschi, N. (2020). The principle of equality in the French Constitutional Council's case-law: what changes after ten years of ex post review implementation? Problemy zakonnosti - Problems of Legality, issue 150, 292-312. doi: https://doi. org/10.21564/2414-990x.150.206778.

Надійшла до редколегії 30.06.2020 p. 